\title{
PENINGKATAN KETRAMPILAN BADAN PERMUSYAWARATAN DESA DALAM PEMBENTUKAN PERATURAN DESA
}

\author{
Fatkhurohman ${ }^{1 *}$ \\ ${ }^{1}$ Fakultas Hukum, Universitas Widyagama Malang \\ *Email Korespondensi: kusumo_uwg@yahoo.co.id
}

\begin{abstract}
ABSTRAK
Dewasa ini desa merupakan primadona baru dalam penyelenggaraan pemerintahan dimana keberadaannya menjadi penting karena negara berusaha untuk membenahi struktur dan fungsinya. Pembenahan ini bertujuan untuk mengangkat harkat dan martabat desa dalam mengemban tugas mensejahterakan masyarakat. Salah satu perangkat penting dalam sistem pemerintahan desa dan mempunyai peran penting untuk mewujudkan desa yang sejahtera adalah Badan Permusyawaratan Desa (BPD). BPD adalah lembaga yang memiliki kewenangan untuk menyepakati lahirnya peraturan desa yang akan menjadi pedoman pelaksanaan pembangunan desa. Tugas BPD adalah membahas dan menyepakati Rancangan Peraturan Desa bersama Kepala Desa, untuk menampung, menyalurkan aspirasi masyarakat desa dan melakukan pengawasan kinerja kepala desa. Permasalahan yang dialami oleh mitra adalah kurangnya pemahaman hak dan kewajiban, serta tujuan pokok dan fungsi para anggota BPD, sehingga mengakibatkan minimnya produk hukum desa yang dihasilkan. Metoda kegiatan ini adalah memberikan penyuluhan hukum kepada anggota BPD Desa Ngenep, Karangploso, Kabupaten Malang. Hasil yang dicapai setelah melakukan kegiatan ini ternyata diketahui bahwa seluruh anggota BPD belum mengetahui secara detail mengenai tugas fungsi dan kewenangan yang dimilikinya. Keberadaan Peraturan Desa (Perdes) sebagai regulasi dipahami secara parsial. Kesimpulannya, pemahaman anggota BPD di Desa Ngenep Kecamatan Karangploso Kabupaten Malang mengenai pemahaman terhadap produk hukum desa dan proses pembentukan yang meliputi peraturan desa, peraturan kepala desa dan keputusan kepala desa yang masih sangat kurang.
\end{abstract}

Kata kunci : BPD, peran fungsi, produk hukum, peraturan desa, peraturan kepala desa

\begin{abstract}
Today, the village is the new prima donna in government administration where its existence becomes essential because the state tries to improve its structure and function. This improvement aims to raise the dignity of the village in carrying out the task of making the community prosperous. One of the essential instruments in the village government system and which has an essential role in realising a prosperous village is the Village Consultative Body (BPD). BPD is an institution that has the authority to agree on the issuance of village regulations that will serve as guidelines for implementing village development. The task of the BPD is to discuss and agree on the Draft Village Regulation with the Village Head, to accommodate, channel the aspirations of the village community and supervise the performance of the village head. The problem experienced by partners is a lack of understanding of the rights and obligations, as well as the main objectives and functions of BPD members, resulting in the lack of village legal products produced. The method of this activity is to provide legal counselling to members of the BPD of Ngenep Village, Karangploso, Malang Regency. The results achieved after carrying out this activity showed that all members of the BPD did not know in detail about their duties, functions and authorities. The existence of a Village Regulation (Perdes) as regulation is partially understood. In conclusion, the understanding of BPD members in Ngenep Village, Karangploso District, Malang Regency regarding the understanding of village law products and the formation process which includes village regulations, village head regulations and village head decisions is still lacking.
\end{abstract}

Keywords : BPD, role functions, legal products, village regulations, village head regulations 


\section{PENDAHULUAN}

Desa adalah unsur terkecil dalam sistem pemerintahan negara Republik Indonesia dimana perannya semakin lama semakin penting untuk mendukung program pembangunan nasional. Sebagai sebuah sistem maka dalam menjalan tugas kewenangan maka desa membentuk sebuah sistem pemerintahan desa. Sistem ini terdiri dari perangkat formal yakni kepala desa sebagai pemegang kendali berjalannya pemerintahan desa dan Badan Permusyawaratan Desa (BPD) yang bertugas sebagai pengawas berjalan roda pemerintahan desa. Selanjutnya BPD merupakan organisasi yang berfungsi sebagai badan yang menetapkan peraturan desa bersama Kepala Desa, menampung dan menyalurkan aspirasi masyarakat. Anggotanya adalah wakil dari penduduk desa bersangkutan yang ditetapkan dengan cara musyawarah dan mufakat. BPD mempunyai peran yang besar dalam membantu Kepala Desa untuk menyusun perencanaan desa dan pembangunan desa secara keseluruhan. Dalam UU Nomor 6 Tahun 2014 BPD mempunyai fungsi:

1) Membahas dan menyepakati Rancangan Peraturan Desa bersama Kepala Desa;

2) Menampung dan menyalurkan aspirasi masyarakat Desa; dan

3) Melakukan pengawasan kinerja Kepala Desa.

Secara tehnis mekanis keberadaan fungsi BPD diatur dalam Peraturan Menteri Dalam Negeri Republik Indonesia No. 110 Tahun 2016 yang menyebutkan BPD berfungsi untuk membahas dan menyepakati Rancangan Peraturan Desa bersama Kepala Desa, menampung dan menyalurkan aspirasi masyarakat desa dan melakukan pengawasan kinerja kepala desa. Dari tiga tugas ini sudah jelas BPD adalah lembaga yang memiliki kewenangan dalam menyepakati peraturan desa (Perdes) yang akan menjadi pedoman pelaksanaan pembangunan desa.

Disisi lain BPD juga memiliki kewenangan untuk menyampaikan aspirasi warga. Penyampaian aspirasi dilakukan melalui beberapa tahap kerja yakni BPD harus melakukan penggalian aspirasi masyarakat, menampung aspirasi masyarakat yang disampaikan ke BPD dan mengelola aspirasi masyarakat sebagai sebuah energi positif dalam merumuskan langkah kebijakan desa (Setneg, 2016). Badan Permuswaratan Desa menyalurkan aspirasi dari warga desa pada kepala desa yang kemudian dijadikan pedoman oleh kepala desa beserta jajarannya dalam melaksanakan program pembangunan desanya. Kewenangan lain yang dimiliki BPD adalah mengawasi proses pembangunan desa dalam seluruh aspek. Ini menunjukkan betapa strategis kewenangan BDP dalam ranah politik dan sosial desa.

Selain itu BPD juga berhak menyenggarakan Musyawarah Desa (Musdes) pada agenda-agenda yang mengharuskan adanya Musdes, salah satunya Musdes membahas rencana lahirnya Badan Usaha Milik Desa (BUMDes). Tanpa persetujuan BPD, BUMDes tak bisa melenggang dan membentuk dirinya. Sekaligus BUMDes adalah salah satu lembaga yang bakal mengawasi jalannya kinerja BUMDes. Adanya UU No. 6 Tahun 2014 tentang Desa yang menempatkan desa sebagai subyek bagi pembangunan di wilayahnya sendiri membuat peran BPD mutlak dan penting. Pasalnya, desa yang selama ini diposisikan sebagai obyek, kini telah menjadi subyek bagi pengembangan potensi dirinya sendiri (Setneg, 2014; Perianto, Yohanes and Yuniarsih, 2019; Yuliananingsih, Novianty and Jumiati, 2019; Nugroho, Raharjo and Hirman, 2020).

Permasalahan yang terjadi saat ini adalah BPD kurang memahami peran dan fungsinya yang sangat strategis, sehingga menyebabkan desa masih mengalami berbagai permasalahan. Permasalahan yang signifikan dari tidak optimalnya peran BPD adalah minimya produk hukum yang dilahirkan oleh BPD. Salah satu desa yang memiliki permasalahan tersebut adalah Desa Ngenep (Dinas komunikasi dan Informatika Kabupaten Malang, 2017).

Desa Ngenep adalah salah satu desa di Kecamatan Karangploso, Kabupaten Malang. Kesadaran pentingnya pendidikan tinggi pemuda maupun masyarakat di Desa Ngenep masih kurang, banyak yang putus sekolah dan melanjutkan bekerja di pabrik. Di Desa Ngenep sendiri terdapat permasalahan lain seperti pengadaan mitra usaha kerja yang belum maksimal 
dan belum dapat terlaksana karena kurangnya akan pengetahuan teknologinya. Wilayah Desa Ngenep terbagi di dalam 15 Rukun Warga (RW) yang tergabung di dalam 8 Dusun dan posisi Kasun (Kepala Dusun) menjadi sangat strategis seiring banyaknya limpahan tugas desa kepada Kasun.

\section{METODE}

Langkah-langkah dalam menyelesaikan permasalahan hukum pada mitra antara lain:

1) Koordinasi dan diskusi dengan mitra tentang program penyuluhan hukum.

2) Penyuluhan hukum.

3) Evaluasi program penyuluhan hukum pada mitra.

\section{HASIL DAN PEMBAHASAN}

Keberadaan BPD dapat dilihat dari Undang-undang No 6 Tahun 2014 tentang BPD dan Permendagri 110 Tahun 2016. Hal ini dilakukan dengan instrument penyuluhan yang keberadaannya diatur dalam Peraturan Menteri Hukum dan HAM RI Nomor: M01.PR.08.10 Tahun 2007 tentang Perubahan atas Peraturan Menteri Hukum dan Hak Asasi Manusia RI Nomor: M-01.PR.08.10 Tahun 2006 tentang Pola Penyuluhan Hukum. Latar belakang keluarnya peraturan menteri tersebut adalah dalam rangka mengembangkan budaya hukum di semua lapisan masyarakat agar dapat tercipta kesadaran dan kepatuhan hukum demi tegaknya supremasi hukum di Negara Kesatuan Republik Indonesia, perlu dilakukan penyuluhan hukum secara nasional dan agar pelaksanaan penyuluhan hukum secara nasional dapat berjalan secara tertib, terarah, dan terpadu, perlu didasarkan pada pola penyuluhan hukum . Adapun beberapa uraian mengenai kewenangan tugas dan fungsi dari BPD adalah akan diuraikan dibawah ini (Menkumham, 2007; Setneg, 2016; Sudjana, 2017; Kanesha, 2018).

BPD adalah atau yang disebut dengan nama lain adalah lembaga yang melaksanakan fungsi pemerintahan yang anggotanya merupakan wakil dari penduduk Desa berdasarkan keterwakilan wilayah dan ditetapkan secara demokratis. BPD mempunyai fungsi :

1) Membahas dan menyepakati Rancangan Peraturan Desa bersama Kepala Desa;

2) Menampung dan menyalurkan aspirasi masyarakat Desa; dan

3) Melakukan pengawasan kinerja Kepala Desa.

Berdasarkan Pasal 56 keberadaan BPD menurut Undang Undang No 6 Tahun 2014 adalah sebagai berikut:

1) Anggota BPD merupakan wakil dari penduduk Desa berdasarkan keterwakilan wilayah yang pengisiannya dilakukan secara demokratis.

2) Masa keanggotaan BPD selama 6 (enam) tahun terhitung sejak tanggal pengucapan sumpah/janji.

3) Anggota BPD sebagaimana dimaksud pada ayat (1) dapat dipilih untuk masa keanggotaan paling banyak 3 (tiga) kali secara berturut-turut atau tidak secara berturutturut.

Dalam Pasal 57 disebutkan bahwa persyaratan calon anggota BPD adalah:

1) Bertakwa kepada Tuhan Yang Maha Esa;

2) Memegang teguh dan mengamalkan Pancasila, melaksanakan Undang-Undang Dasar Negara Republik Indonesia Tahun 1945, serta mempertahankan dan memelihara keutuhan Negara Kesatuan Republik Indonesia dan Bhinneka Tunggal Ika;

3) Berusia paling rendah 20 (dua puluh) tahun atau sudah/pernah menikah;

4) Berpendidikan paling rendah tamat sekolah menengah pertama atau sederajat;

5) Bukan sebagai perangkat Pemerintah Desa;

6) Bersedia dicalonkan menjadi anggota Badan Permusyawaratan Desa; dan

7) Wakil penduduk Desa yang dipilih secara demokratis. 
Berdasarkan Pasal 58 disebutkan bahwa:

1) Jumlah anggota BPD ditetapkan dengan jumlah gasal, paling sedikit 5 (lima) orang dan paling banyak 9 (sembilan) orang, dengan memperhatikan wilayah, perempuan, penduduk, dan kemampuan Keuangan Desa.

2) Peresmian anggota BPD sebagaimana dimaksud pada ayat (1) ditetapkan dengan keputusan Bupati/Walikota.

3) Anggota BPD sebelum memangku jabatannya bersumpah/berjanji secara bersama-sama di hadapan masyarakat dan dipandu oleh Bupati/Walikota atau pejabat yang ditunjuk.

4) Susunan kata sumpah/janji anggota BPD sebagai berikut:

"Demi Allah/Tuhan, saya bersumpah/berjanji bahwa saya akan memenuhi kewajiban saya selaku anggota Badan Permusyawaratan Desa dengan sebaik-baiknya, sejujurjujurnya, dan seadil-adilnya; bahwa saya akan selalu taat dalam mengamalkan dan mempertahankan Pancasila sebagai dasar negara, dan bahwa saya akan menegakkan kehidupan demokrasi dan Undang-Undang Dasar Negara Republik Indonesia Tahun 1945 serta melaksanakan segala peraturan perundang-undangan dengan seluruslurusnya yang berlaku bagi Desa, daerah, dan Negara Kesatuan Republik Indonesia".

Keberadaan Struktur organisasi BPD diatur dalam Pasal 59 yang menyebutkan bahwa:

1) Pimpinan BPD terdiri atas 1 (satu) orang ketua, 1 (satu) orang wakil ketua, dan 1 (satu) orang sekretaris.

2) Pimpinan BPD sebagaimana dimaksud pada ayat (1) dipilih dari dan oleh anggota BPD secara langsung dalam rapat BPD yang diadakan secara khusus.

3) Rapat pemilihan pimpinan BPD untuk pertama kali dipimpin oleh anggota tertua dan dibantu oleh anggota termuda.

Seperti disebutkan pada Pasal 61, bahwa BPD berhak:

1) Mengawasi dan meminta keterangan tentang penyelenggaraan Pemerintahan Desa kepada Pemerintah Desa;

2) Menyatakan pendapat atas penyelenggaraan Pemerintahan Desa, pelaksanaan Pembangunan Desa, pembinaan kemasyarakatan Desa, dan pemberdayaan masyarakat Desa; dan

3) Mendapatkan biaya operasional pelaksanaan tugas dan fungsinya dari Anggaran Pendapatan dan Belanja Desa.

Untuk kepentingan peran BPD dalam pembentukan Perdes bisa dilihat Pasal 62 yang menyebutkan anggota BPD berhak:

1) Mengajukan usul rancangan Peraturan Desa;

2) Mengajukan pertanyaan;

3) Menyampaikan usul dan/atau pendapat;

4) Memilih dan dipilih; dan

5) Mendapat tunjangan dari Anggaran Pendapatan dan Belanja Desa.

Perlu diketahui disamping Perdes, produk hukum Desa juga meliputi beberapa jenis antara lain;

1) Peraturan Kepala Desa;

2) Peraturan Bersama Kepala Desa;

3) Keputusan Kepala Desa.

4) Dalam menjalankan tugas berdasarkan Pasal 63 Anggota BPD wajib:

5) Memegang teguh dan mengamalkan Pancasila, melaksanakan Undang-Undang Dasar Negara Republik Indonesia Tahun 1945, serta mempertahankan dan memelihara keutuhan Negara Kesatuan Republik Indonesia dan Bhinneka Tunggal Ika;

6) Melaksanakan kehidupan demokrasi yang berkeadilan gender dalam penyelenggaraan Pemerintahan Desa;

7) Menyerap, menampung, menghimpun, dan menindaklanjuti aspirasi masyarakat Desa;

8) Mendahulukan kepentingan umum di atas kepentingan pribadi, kelompok, dan/atau golongan;

9) Menghormati nilai sosial budaya dan adat istiadat masyarakat Desa; dan 
10) Menjaga norma dan etika dalam hubungan kerja dengan lembaga kemasyarakatan Desa. Disamping anggota BPD harus melaksanakan kewajiban, berdasarkan Pasal 64 Anggota BPD dilarang:

1) Merugikan kepentingan umum, meresahkan sekelompok masyarakat Desa, dan mendiskriminasikan warga atau golongan masyarakat Desa;

2) Melakukan korupsi, kolusi, dan nepotisme, menerima uang, barang, dan/atau jasa dari pihak lain yang dapat memengaruhi keputusan atau tindakan yang akan dilakukannya;

3) Menyalahgunakan wewenang;

4) Melanggar sumpah/janji jabatan;

5) Merangkap jabatan sebagai Kepala Desa dan perangkat Desa;

6) Merangkap sebagai anggota Dewan Perwakilan Rakyat Republik Indonesia, Dewan Perwakilan Daerah Republik Indonesia, Dewan Perwakilan Rakyat Daerah Provinsi atau Dewan Perwakilan Rakyat Daerah Kabupaten/Kota, dan jabatan lain yang ditentukan dalam peraturan perundangan-undangan;

7) Sebagai pelaksana proyek Desa;

8) Menjadi pengurus partai politik; dan/atau

9) Menjadi anggota dan/atau pengurus organisasi terlarang.

Mekanisme pengesahan Perdes harus dibahas bersama sama antara BPD dengan pihak

Pemerintah Desa, juga melibatkan masyarakat melalui sebuah forum musyawarah desa (Musdes). Hal ini seperti disebutkan dalam Pasal 65 yang menyebutkan;

1) Mekanisme musyawarah BPD sebagai berikut:

a. Musyawarah BPD dipimpin oleh pimpinan BPD;

b. Musyawarah BPD dinyatakan sah apabila dihadiri oleh paling sedikit 2/3 (dua pertiga) dari jumlah anggota BPD;

c. Pengambilan keputusan dilakukan dengan cara musyawarah guna mencapai mufakat;

d. Apabila musyawarah mufakat tidak tercapai, pengambilan keputusan dilakukan dengan cara pemungutan suara;

e. Pemungutan suara sebagaimana dimaksud dalam huruf d dinyatakan sah apabila disetujui oleh paling sedikit $1 / 2$ (satu perdua) ditambah 1 (satu) dari jumlah anggota BPD yang hadir; dan

f. Hasil musyawarah BPD ditetapkan dengan keputusan BPD dan dilampiri notulen musyawarah yang dibuat oleh sekretaris BPD.

2) Ketentuan lebih lanjut mengenai BPD diatur dalam Peraturan Daerah Kabupaten/Kota.

Dalam kegiatan penyuluhan hukum bagi anggota BPD Desa Ngenep, Kecamatan Karangploso Kabupaten Malang penulis memahamkan tentang terbentuknya Perdes melalui bagan-bagan seperti pada Gambar 1-3 sebagai berikut. Sedangkan foto-foto kegiatan dapat dilihat pada Gambar 4. 


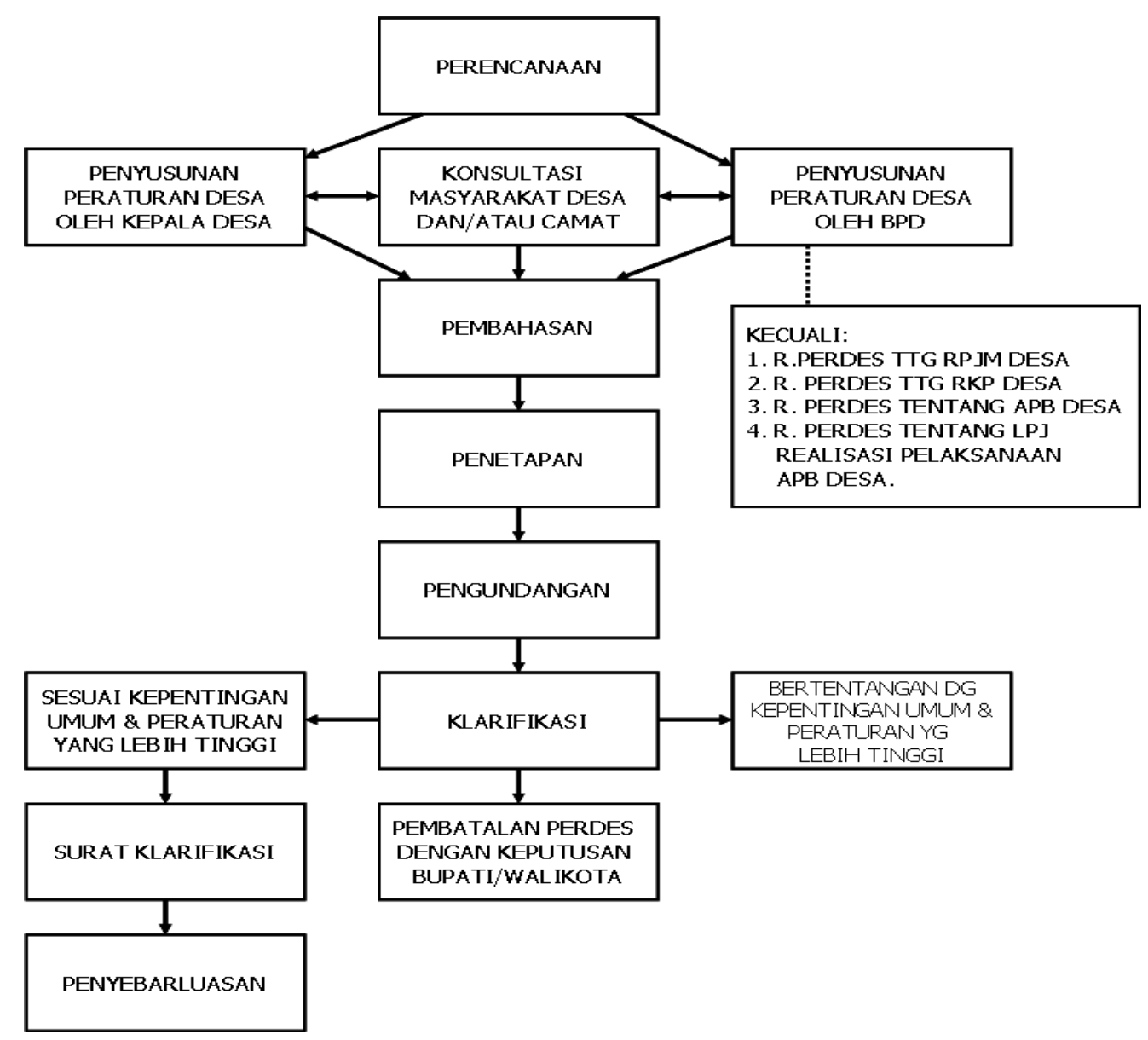

Gambar 1. Alur Penyusunan sampai Penetapan Perdes 1 


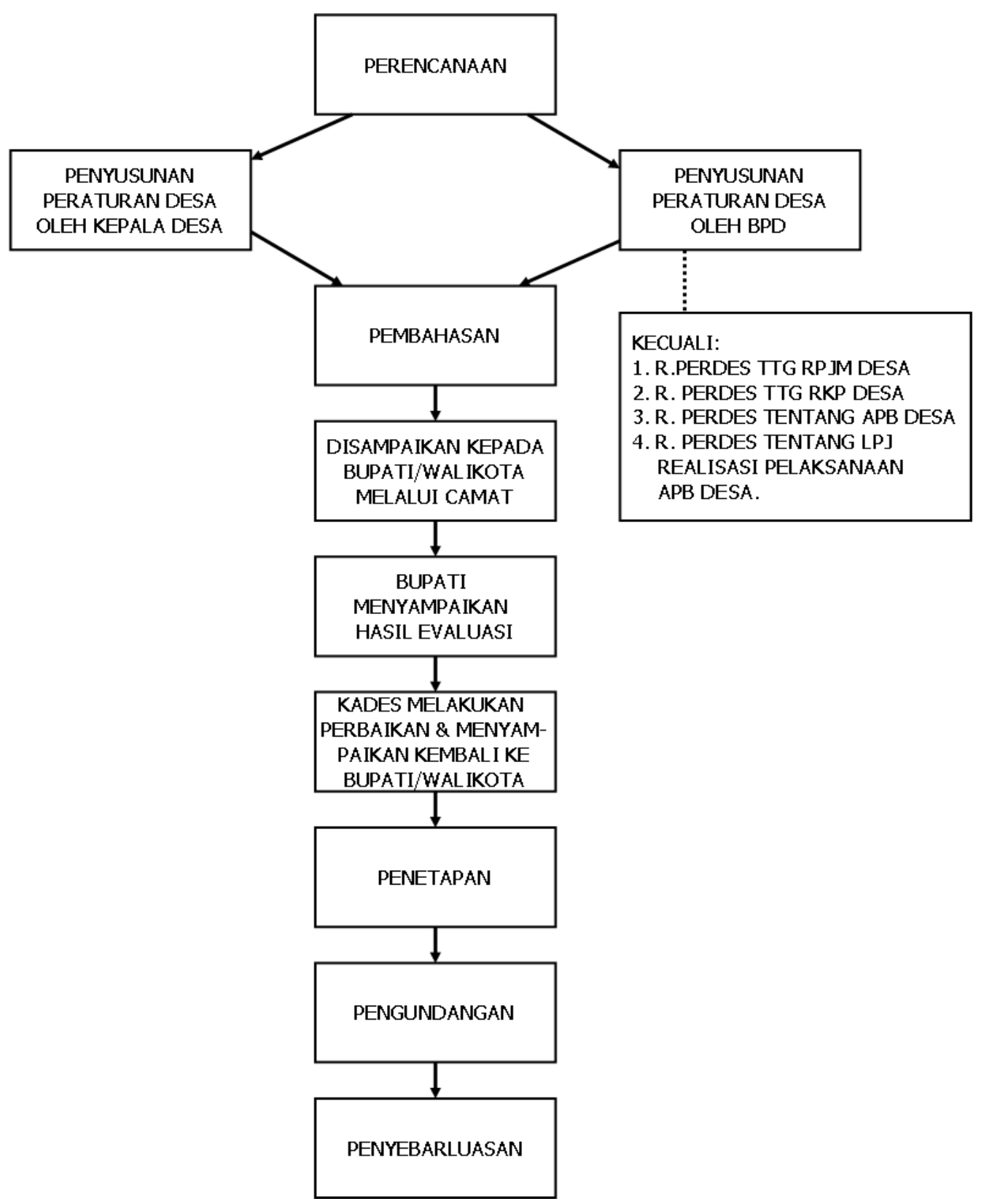

Gambar 2. Alur Penyampaian Perdes Ke Bupati atau Walikota 


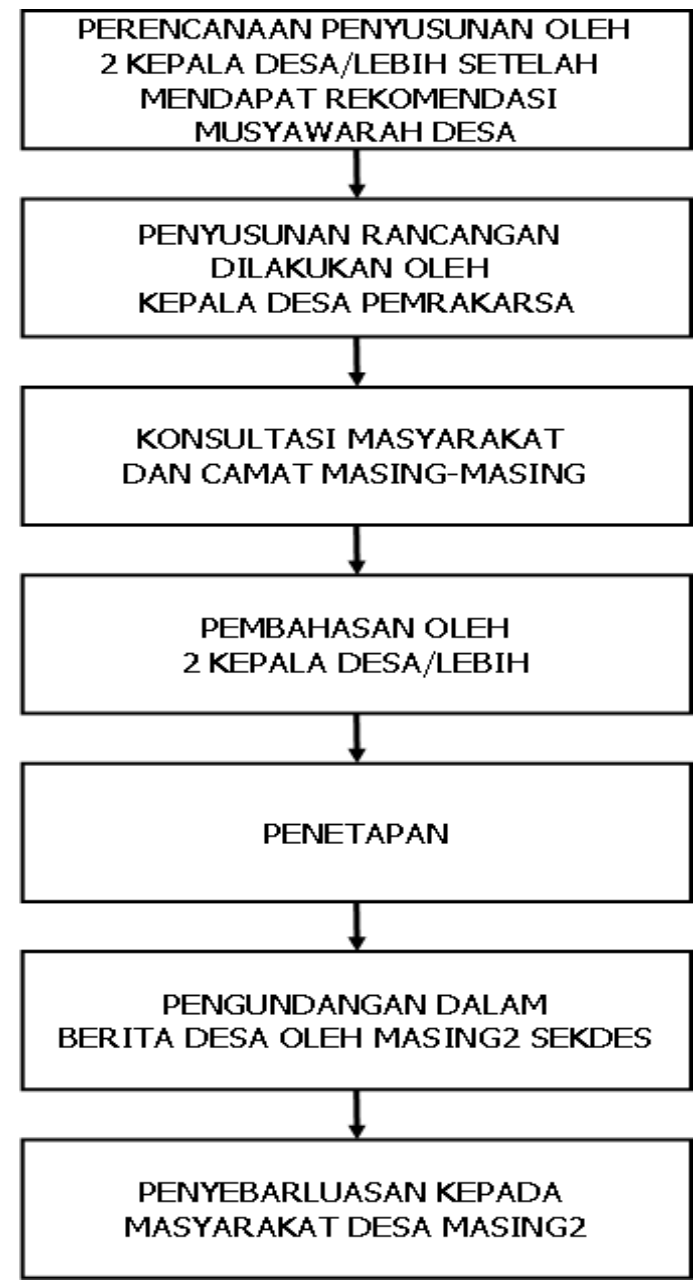

Gambar 3. Alur Penyusunan sampai Penetapan Perdes oleh Lebih Satu Kepala Desa 

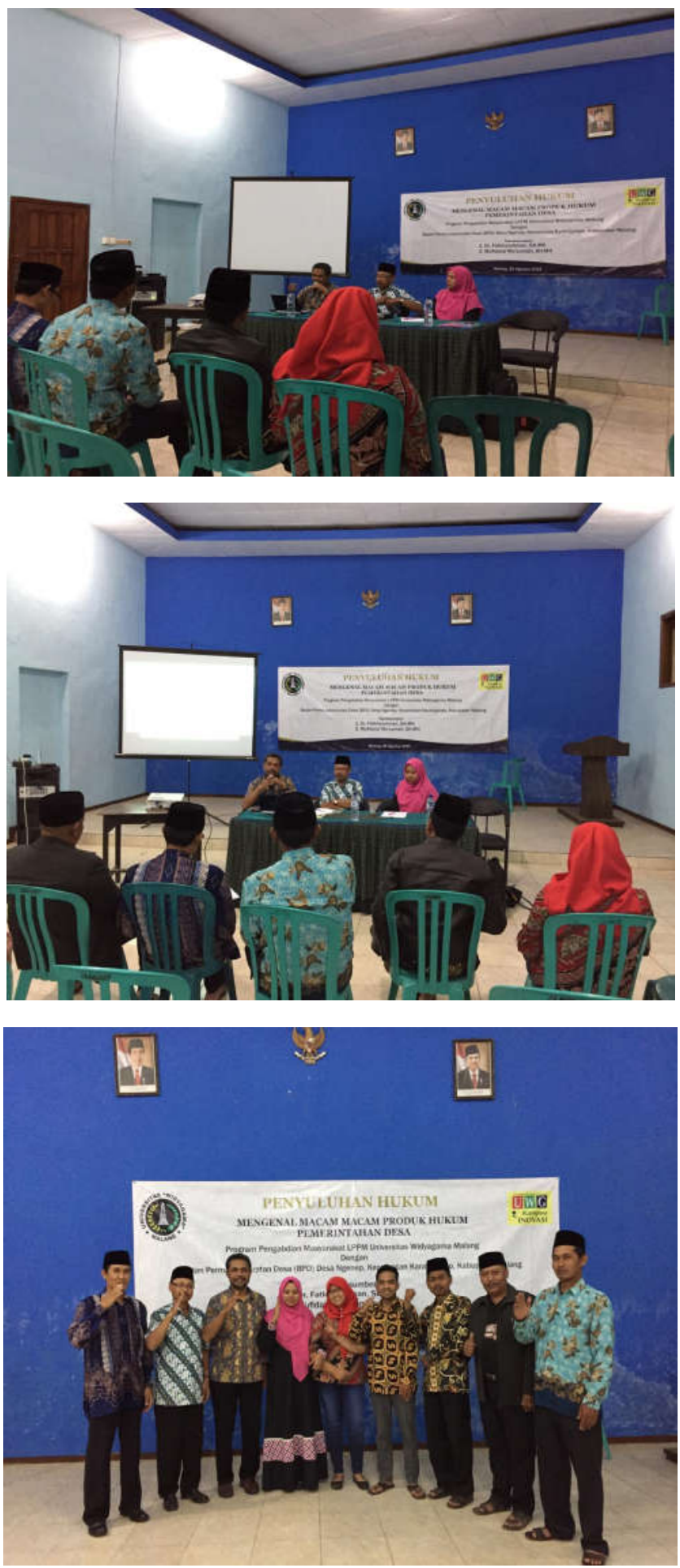

Gambar 4. Kegiatan Penyuluhan Hukum Bersama Anggota BPD dan Perangkat Desa di Desa Ngenep Kecamatan Karangploso Kabupaten Malang 


\section{DAMPAK DAN MANFAAT}

Anggota BPD lebih memahami dengan jelas terhadap produk hukum desa yang meliputi peraturan desa, peraturan kepala desa dan keputusan kepala desa di Desa Ngenep, Kecamatan Karangploso, Kabupaten Malang. Demikian juga tentang mekanisme terbentuknya berbagai produk hukum desa mulai perencanaan pembentukan pembahasan sampai dengan pengundangan lebih dipahami secara detail oleh seluruh anggota BPD.

\section{KESIMPULAN}

Pemahaman anggota BPD di Desa Ngenep, Kecamatan Karangploso, Kabupaten Malang mengenai pemahaman terhadap produk hukum desa yang meliputi peraturan desa, peraturan kepala desa dan keputusan kepala desa masih sangat kurang. Begitu pula dengan mekanisme terbentuknya berbagai produk hukum desa mulai perencanaan pembentukan pembahasan sampai dengan pengundangan belum dipahami secara detail oleh seluruh anggota BPD. Adapun saran yang dapat diberikan pada kegiatan kali ini untuk perbaiki kedepannya adalah perlu buku saku bagi seluruh anggota Badan Permusyawaratan Desa Desa Ngenep Kecamatan Karangploso Kab. Malang. Serta, perlu pendampingan yang lebih intensif dan nyata bagi seluruh anggota BPD dalam proses pembentukan produk hukum desa.

\section{UCAPAN TERIMA KASIH}

Ucapan terima kasih disampaikan kepada LPPM dan pimpinan Universitas Widyagama Malang yang telah memberikan dana pengabdian masyarakat, serta masyarakat, anggota BPD dan perangkat desa di Desa Ngenep, Kecamatan Karangploso, Kabupaten Malang sehingga kegiatan ini dapat berjalan dengan lancar.

\section{REFERENSI}

Dinas komunikasi dan Informatika Kabupaten Malang (2017) Desa Ngenep. Available at: http://desa-ngenep.malangkab.go.id/ (Accessed: 24 September 2020).

Kanesha, R. (2018) 'Implementasi Peraturan Menteri Dalam Negeri Nomor 110 Tahun 2016 Tentang Badan Permusyawaratan Desa Terkait Dengan Pembentukan Peraturan Desa di Kecamatan Sungai Raya Kabupaten Kubu Raya', Jurnal NESTOR Magister Hukum, 3(3).

Menkumham (2007) 'Peraturan Menteri Hukum dan HAM RI Nomor: M-01.PR.08.10 Tahun 2007 Tentang Perubahan atas Peraturan Menteri Hukum dan Hak Asasi Manusia RI Nomor: M-01.PR.08.10 Tahun 2006 Tentang Pola Penyuluhan Hukum'.

Nugroho, S. S., Raharjo, M. and Hirman, H. (2020) 'Penyuluhan Hukum: Pendirian Dan Pemberdayaan Bum Desa Mendak Kecamatan Dagangan Kabupaten Madiun', JURNAL DAYA-MAS, 5(1), pp. 12-15.

Perianto, Yohanes, Y. and Yuniarsih, R. (2019) 'Fungsi Badan Permusyawaratan Desa Dalam Pengawasan Rencana Kerja Pemerintah Desa Tebing Batu Kecamatan Sebawi Kabupaten Sambas', GOVERNANCE-Jurnal Ilmu Pemerintahan, 8(3).

Setneg (2014) 'Undang-Undang Nomor 6 Tahun 2014 tentang Desa'.

Setneg (2016) 'Peraturan Menteri Dalam Negeri Republik Indonesia Nomor 110 Tahun 2016 tentang Badan Permusyawaratan Desa'.

Sudjana (2017) 'Penyuluhan Hukum Dalam Upaya Peningkatan Kesadaran Hukum Berlalulintas Melalui Pemahaman Terhadap Isi Undang-Undang Nomor 22 Tahun 2009 Tentang Lalu Lintas Dan Angkutan Jalan', Jurnal Pendidikan Ilmu Sosial, 25(2), p. 124. doi: 10.17509/jpis.v25i2.6186. 
Yuliananingsih, Y., Novianty, F. and Jumiati, J. (2019) 'Fungsi Badan Permusyawaratan Desa (BPD) Dalam Mengawasi Kinerja Kepala Desa di Desa Sungai Besar Kecamatan Bunut Hulu Kabupaten Kapuas Hulu', Sosial Horizon: Jurnal Pendidikan Sosial, 6(1), pp. 123-134. 